\title{
Evaluating changes in nitrogen and sulphur content in a soil-plant system in a long-term fertilization experiment
}

\author{
Evelin Kármen Juhász - Andrea Balláné Kovács \\ University of Debrecen, Faculty of Agricultural and Food Sciences and Environmental Management, Institute of Agricultural Chemistry and \\ Soil Science, Debrecen \\ evelinjuhasz570@gmail.com
}

\section{SUMMARY}

\begin{abstract}
The objective of this study was to evaluate the impact of long term NPK fertilization (considering that $S$ containing superphosphate was supplied for 26 years of experiment, but since 9 years $S$ has not used any longer) on sulphur-and nitrogen content and N/S ratio of winter wheat. The second objective of this work was to determine the changes of the amount of the different nitrogen and sulphur fraction in chernozem soil in a long term fertilization experiment. The third aim of the work was to determine if a relationship could be established between the studied parameters. Based on our results, it can be stated that the sulphur containing superphosphate supplied in the period of 1984-2010 has no longer significant effect on total sulphur content of plant in 2018. The NPK fertilization treatments had positive effect on total nitrogen content of winter wheat. In general, increasing NPK doses resulted in significantly higher nitrogen. The effect of irrigation applied in previous years has no statistically significant effect on the sulphur and nitrogen content of wheat. The wheat grain produced in our experiment, especially in fertilized treatments showed $S$ deficiency. Analysing the changes of $\mathrm{CaCl}_{2}$ soluble nitrate- $\mathrm{N}$ and total $\mathrm{N}$ of the soil, it can be stated that the effect of increasing fertilizer doses clearly appears in these parameters, because the treatment with increasing fertilizer doses resulted higher $\mathrm{CaCl}_{2}$ soluble $\mathrm{N}$ forms compared to the control treatment in soil. These values increased until flowering stage of wheat and after that a slightly decrease was observed as a result of higher $N$ uptake of plant. In overall, it can be stated, that the effect of superphosphate on measured sulphur fraction is prevailed. With increasing fertilizer doses higher sulphate content was detected in soil, but the sulphate content measured in different soil extractant is not enough for the wheat in this experiment area. Studying the correlation between the measured parameters of plant and soil, it can be concluded, that the relationships between nitrogen in the plant and in the soil is stable, and did not change during the growing season. The correlation between plant $S$ and soil $S$ varied in the measured periods and the r value was low in most cases. At the stage of flowering the highest $r$ value was found between $\mathrm{KCl}_{-} \mathrm{SO}_{4}$ and plant $\mathrm{S}$. In the stage of ripening the strongest correlation was detected between $\mathrm{KH}_{2} \mathrm{PO}_{4}-\mathrm{SO}_{4}$ and grain $\mathrm{S}$ content.
\end{abstract}

Keywords: long-term fertilization experiment, nitrogen, sulphur, plant-soil system

\section{INTRODUCTION}

Plant growth, yield and yield stability in field crop production are determined by a complex interaction of environmental, biological and agro-technical management factors. The impacts and interactions between these factors can be studied most effectively in long-term experiments (Pepó, 2015).

Sulphur deficiency can be an increasing problem in many agricultural areas. The sulphur content of the soils is constantly decreasing, which can be traced back to several reasons. Traditional fertilisers which contain considerable amounts of $\mathrm{S}$, such as ammonium sulphate and single superphosphate, have been replaced progressively by fertilisers containing little or no $\mathrm{S}$ (Zhao and McGrath, 1994; Kalocsai et al., 2003). One of the most important reasons of increasing $\mathrm{S}$ deficiency has been the massive decrease in the inputs of $\mathrm{S}$ from atmospheric deposition. The decreasing trend in sulphur dioxide emissions, as required by international agreements, is likely to continue well into the next decade (Zhao et al., 1999).

Without proper available $S$, crops neither can reach their full potential in terms of yield, quality or protein content; nor can they make efficient use of applied nitrogen (Sahota, 2006). At high $\mathrm{N}$ fertilization levels significant responses to sulphur fertilization were found which emphasised the need for precision use of sulphur in intensive wheat production systems. Continuous application of $\mathrm{N}$ fertilizer without supplemental sulphur on low sulphur soils will reduce wheat flour quality (Ruiter and Martin, 2001; Flaete et al., 2005).

Nitrogen plays a central role in plant productivity because nitrogen is a major component of amino acids, proteins, nucleic acids, and chlorophyll. Nitrogen promotes rapid growth, increases leaf size and quality, hastens crop maturity, and promotes fruit and seed development (Parsons and Tinsley, 1975). Sulphur is an essential nutrient for plants. Proper sulphur delivery has a positive effect on the vegetative growth of plants, increases green weight, modifies protein content, and influences the amount and proportion of proteinforming amino acids (methionine, cysteine). Increasing sulphur deficiency in plants can reduce the utilization and absorption of other nutrients, especially nitrogen (Barney and Bush, 1985; Hesse et al., 2004). Because of central role of $\mathrm{S}$ and $\mathrm{N}$ in the synthesis of proteins, the supplies of these nutrients in plants are highly interrelated. Sulphur and nitrogen relationships were established in many studies (McGrath and Zhao, 1996; Ahmad et al., 1998; and Jamal et al., 2005; 2006; 2010) in terms of dry matter and yield in several crops.

The objective of this study was to evaluate the impact of long term NPK fertilization (considering that $S$ containing superphosphate was supplied for 26 years of experiment, but since 9 years $\mathrm{S}$ has not used any longer) on sulphur- and nitrogen content and N/S ratio of winter wheat. The second objective of this work was to determine the changes of amount of the different nitrogen and sulphur fraction in chernozem soil in a 
long term fertilization experiment. The third aim of the work was to determine if a relationship could be established between the studied parameters.

\section{MATERIALS AND METHODS}

A long-term field experiment was established at the Research Station of Látókép of the University of Debrecen in 1984, by Ruzsányi László. It is located 15 $\mathrm{km}$ from Debrecen in Hungary. The long-term experimental site is characterized by continental climatic conditions. The average total annual precipitation in 2018 was $607.7 \mathrm{~mm}$ and average annual yearly mean temperature is $12.07{ }^{\circ} \mathrm{C}$. The soil is a calcareous chernozem (Chernozem by WRB) with 2.8 $3.0 \%$ humus content. The depth of the humus layer is $70-90 \mathrm{~cm}$. Main parameters of the experimental soil are $\mathrm{pH}(\mathrm{KCl})=7.06 ; \mathrm{Hu} \%=2.8 ; \mathrm{K}_{\mathrm{A}}=37.5 ; \mathrm{AL}-\mathrm{P}_{2} \mathrm{O}_{5}=3$ $94.1 \mathrm{mg} \mathrm{kg}^{-1} ; \mathrm{AL}-\mathrm{K}_{2} \mathrm{O}=190.8 \mathrm{mg} \mathrm{kg}{ }^{-1} ; \mathrm{KH}_{2} \mathrm{PO}_{4}-\mathrm{SO}_{4}{ }^{2-}$ $=43.6 \mathrm{mg} \mathrm{kg}^{-1} ; \mathrm{AL}-\mathrm{Ca}=5130 \mathrm{mg} \mathrm{kg}^{-1} ; \mathrm{AL}-\mathrm{Mg}=403.0$ $\mathrm{mg} \mathrm{kg}^{-1}$. The examined treatments of long term experiment can be seen in Table 1 .

Table 1

Rates of mineral fertilizers applied in the experiment (Látókép)

\begin{tabular}{|c|c|c|c|c|}
\hline \multicolumn{2}{|c|}{ Treatments } & \multirow{2}{*}{$\begin{array}{c}\begin{array}{c}\mathrm{N} \\
\left(\mathrm{kg} \mathrm{ha}^{-1}\right)\end{array} \\
0\end{array}$} & \multirow{2}{*}{$\begin{array}{c}\begin{array}{c}\mathbf{P}_{2} \mathbf{O}_{5} \\
\left(\mathrm{~kg} \mathrm{ha}^{-1}\right)\end{array} \\
0\end{array}$} & \multirow{2}{*}{$\begin{array}{c}\begin{array}{c}\mathrm{K}_{2} \mathrm{O} \\
\left(\mathrm{kg} \mathrm{ha}^{-1}\right)\end{array} \\
0\end{array}$} \\
\hline \multirow{3}{*}{ irrigated } & control & & & \\
\hline & NPK1 & 100 & 70 & 80 \\
\hline & NPK2 & 200 & 140 & 160 \\
\hline \multirow{3}{*}{$\begin{array}{c}\text { non- } \\
\text { irrigated }\end{array}$} & control & 0 & 0 & 0 \\
\hline & NPK1 & 100 & 70 & 80 \\
\hline & NPK2 & 200 & 140 & 160 \\
\hline
\end{tabular}

Each treatment consists of $46 \mathrm{~m}^{2}$ plots, arranged in a randomized block design with four replications. Besides control the effect of two levels of NPK fertilizer doses have been investigated. Winter wheat and corn were cropped in a crop rotation on plots.

Between 1984 and 2010 years the N, P, K nutrients were supplied as $\mathrm{NH}_{4} \mathrm{NO}_{3}$, superphosphate and $\mathrm{KCl}$, respectively in the experiment. The superphosphate is a sulphur containing fertilizer, with $10.9 \%$ sulphur content. From 2010 the superphosphate was replaced by monoammonium dihydrogen phosphate (MAP) and sulphur was not supplied any more in this area. The solid N, P, K fertilizers were mixed into the soil before sowing.

In the soil sampling year (2018) there was $25 \mathrm{~mm}$ rain in April, $55 \mathrm{~mm}$ in May and $55 \mathrm{~mm}$ in June, and there was no need to irrigate in the experimental area. However, irrigation performed in the previous years makes it possible to distinguish irrigated and nonirrigated areas.

Plant samples were taken in three different development stages of winter wheat based on $\mathrm{BBCH}$ scale: at the stage of $\mathrm{BBCH} 30-32, \mathrm{BBCH} 61-65$ and BBCH 89.

Soil samples were collected from the topsoil 0-20 $\mathrm{cm}$ of experimental plots at the time of plant sampling.
Soil samples were air dried, ground and passed through a $2 \mathrm{~mm}$ sieve.

The total nitrogen and total sulphur content of plant at different development stage and wheat grain were measured by Elementar Vario EL type CNS analyser. $\mathrm{N} / \mathrm{S}$ ratios of leaves in different growing stage and the same values of wheat grain were calculated.

Water-soluble inorganic sulphate was extracted with $1 \mathrm{M} \mathrm{KCl}$ and $0.01 \mathrm{M} \mathrm{CaCl}_{2}$ solution. The soluble plus adsorbed sulphate was extracted with $0.016 \mathrm{M}$ $\mathrm{KH}_{2} \mathrm{PO}_{4}$ extractant. $10 \mathrm{~g}$ soil was shaken with $25 \mathrm{ml}$ extractants in all cases. Extracts were filtered and sulphate was measured by turbidimetric method (Zhao and McGrath, 1994). This method based on the forming of $\mathrm{BaSO}_{4}$ precipitate in a slightly acid medium when excess $\mathrm{BaCl}_{2} * 2 \mathrm{H}_{2} \mathrm{O}$ is added to a solution containing sulphate-S. Concentration of different nitrogen forms $\left(\mathrm{NO}_{3}{ }^{-} \mathrm{N}\right.$ and total-N) were measured in $0.01 \mathrm{M} \mathrm{CaCl}_{2}$ extracts with 1:10 soil: solution ratio (Houba et al., 1991) by auto-analyser (SKALAR Segment Flow Analyser).

For statistical analysis of experimental results IBM SPSS Statistics 22 and Microsoft Excel 2016 programs were used. The mean values of each treatment group were subjected to comparisons analysis using the OneWay ANOVA (significance level of $\mathrm{p}<0.05$ ) with post hoc comparisons using Tukey test and Pearson's linear correlation was used to determine the relationship between nutrient content of the soil and plant. The measured values were analysed separately in three different development stages of winter wheat.

\section{RESULTS AND DISCUSSION}

\section{$\mathrm{N}$-and $\mathrm{S}$ content of plant and soil at the stage of BBCH 30-32 of wheat}

At the development stage of $\mathrm{BBCH} 30-32$ the nitrogen content of winter wheat ranged between 1.91$4.41 \%$ (Figure 1). Mars (2009) estimated similar values $(2.22-4.27 \%)$ at this stage of winter wheat in a long term-fertilization experiments. There was no significant difference between plant $\mathrm{N}$ in irrigated and in non-irrigated area. The increasing fertilizer doses resulted higher nitrogen content of plant, and this was statistically proven compared to the control treatment.

The sulphur content of winter wheat at this development stage varied between from 0.18 to $0.21 \%$ and Kulhánek et al. (2014) measured comparable values of winter wheat $(0.18-0.31 \%)$ in a long termfield experiments. The increasing fertilizer doses and irrigation had no statistically significant effect on the sulphur content of winter wheat at this growth stage.

At this stage the N/S ratio of wheat ranged between $10.37-22.23$ values. The narrowest N/S ratio was found in the control treatment both in irrigated and nonirrigated areas and these values enhanced due to the increasing NPK doses. It can be stated, that the nitrogen content increased at greater extent due to NPK fertilization than the sulphur content. According to Cram (1990) it has been established that the N/S ratio in the whole plant in general is 20:1. Similar value was 
obtained in NPK1 and NPK2 treatment of our experiment.

Concentrations of $0.01 \mathrm{M} \mathrm{CaCl}_{2}$ soluble $\mathrm{NO}_{3}{ }^{-}$of soil at the stage of BBCH 30-32 varied between 0.254 and $2.150 \mathrm{mg} \mathrm{kg}^{-1}$ in all treatments (Table 2). The smallest value was found in control treatment both in irrigated and non-irrigated area. The soil $\mathrm{NO}_{3}{ }^{-} \mathrm{N}$ content enhanced with increasing doses of NPK fertilizer compared to the control treatment, but the significant higher effect was observed only in the highest fertilization treatment in irrigated variant. The $0.01 \mathrm{M}$ $\mathrm{CaCl}_{2}$ soluble total $\mathrm{N}$ content ranged between 1.119 $4.751 \mathrm{mg} \mathrm{kg}^{-1}$ in all treatments. The increasing effect of NPK fertilizer on the $0.01 \mathrm{M} \mathrm{CaCl}_{2}$ soluble total $\mathrm{N}$ also appeared. Higher total $\mathrm{N}$ content was observed in fertilized plots compared to the control treatment. There was no significant effect of irrigation on $0.01 \mathrm{M}$ $\mathrm{CaCl}_{2}$ soluble $\mathrm{NO}_{3}{ }^{-}$and total $\mathrm{N}$ except in the case of $\mathrm{NO}_{3}{ }^{-}$content in the NPK2 treatment.
At the stage of development of $\mathrm{BBCH} 30-32$ the $\mathrm{CaCl}_{2}$ soluble $\mathrm{SO}_{4}{ }^{2-}$ content of soil ranged between $0.293-1.047 \mathrm{mg} \mathrm{kg}^{-1}$. $\mathrm{CaCl}_{2}$ is a weak salt solution and it solves the water soluble inorganic fraction (Hu et al., 2005). It is clear, from Table 2 , that there were usually no significant differences between studied treatments, but there were visible trends in increase of the S content in soil with increasing fertilizer rate. Higher $\mathrm{CaCl}_{2}$ soluble $\mathrm{SO}_{4}{ }^{2-}$ content was measured in irrigated area in all treatments, but this effect was not statistically proven.

The $\mathrm{KCl}$ soluble $\mathrm{SO}_{4}^{2-}$ represents the water-soluble inorganic sulphate fraction of soil as well as $\mathrm{CaCl}_{2}$ soluble $\mathrm{SO}_{4}{ }^{2}$. The smallest value was always found in the control treatment and the increasing fertilizer doses resulted higher sulphate content compared to the control treatment. In this case higher sulphate content was observed in non-irrigated plots compared to the $\mathrm{CaCl}_{2}$ soluble $\mathrm{SO}_{4}{ }^{2-}$ content.

Figure 1: Changes of N-, S- content and N/S ratio of winter wheat at the stage of BBCH 30-32

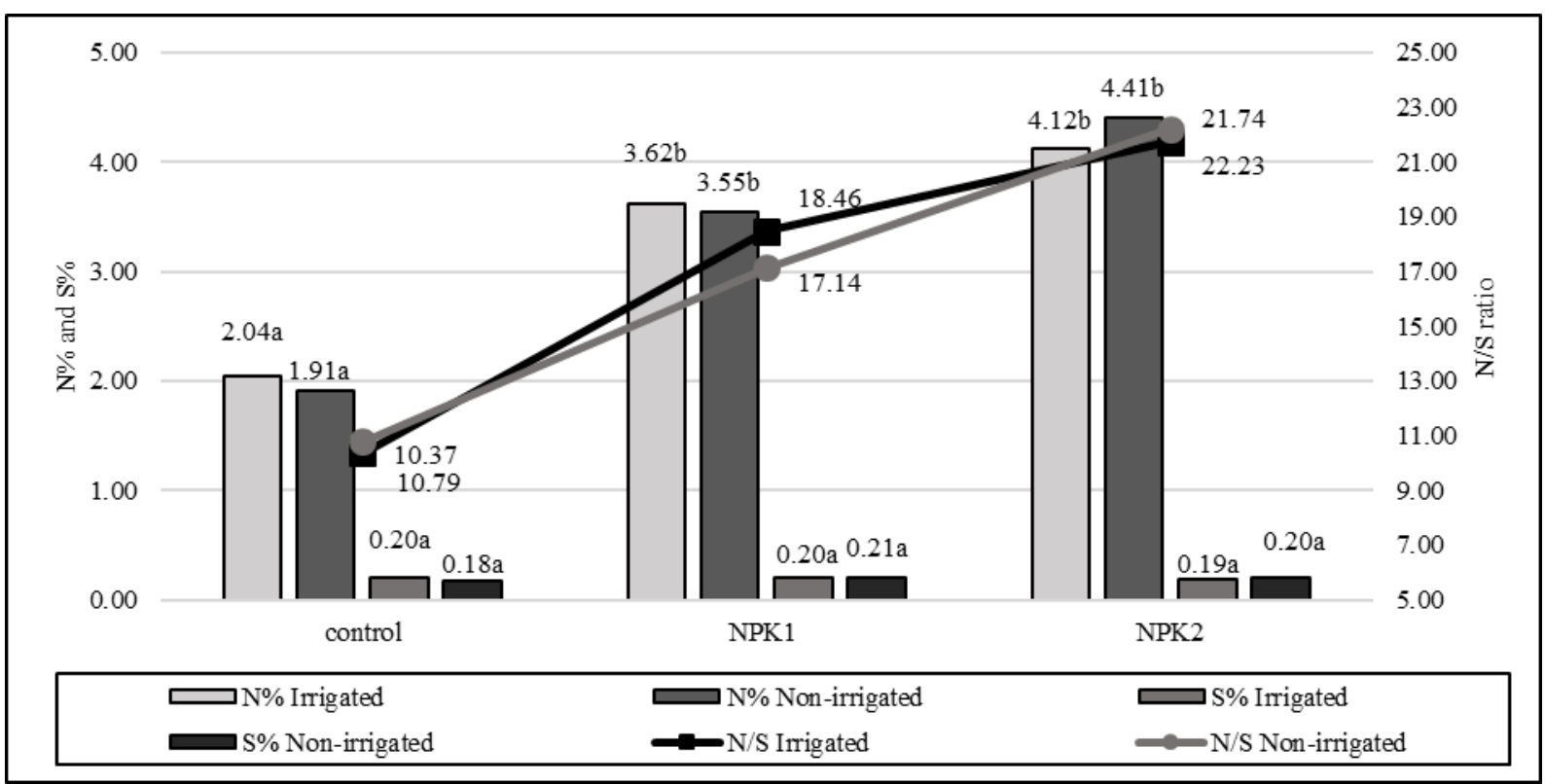

Note: Data marked with the same letter is not significantly different at the significant level of $\mathrm{p}<0.05$

Based on the results (Table 2), the values of $\mathrm{KH}_{2} \mathrm{PO}_{4}-\mathrm{SO}_{4}{ }^{2-}$ were higher than $1 \mathrm{M} \mathrm{KCl}$ soluble $\mathrm{SO}_{4}{ }^{2-}$ and the $0.01 \mathrm{M} \mathrm{CaCl}{ }_{2}-\mathrm{SO}_{4}{ }^{2-}$, because $\mathrm{KH}_{2} \mathrm{PO}_{4}$ may extract not only the soluble $\mathrm{SO}_{4}{ }^{2-}$ but the adsorbed fraction as well. It can be stated, that higher $\mathrm{KH}_{2} \mathrm{PO}_{4}$ soluble sulphate content was found in irrigated area in all treatments compared to the non-irrigated variant.
There were no high differences between the control and fertilized treatments, only the highest fertilizer dose caused a little increment in sulphate content in the irrigated area. However, in the non-irrigated area, the treatments with increasing fertilizer doses resulted decreased sulphate-values. 
$\mathrm{NO}_{3}^{-}$, Total $\mathrm{N}$ and $\mathrm{SO}_{4}{ }^{2-}-$ content of soil at the stage of $\mathrm{BBCH} 30-32$ of winter wheat

\begin{tabular}{|c|c|c|c|c|c|c|}
\hline \multicolumn{2}{|c|}{ Treatments } & $\begin{array}{c}0.01 \mathrm{M} \mathrm{CaCl}_{2-}^{-} \\
\mathrm{NO}_{3}^{-} \\
\left(\mathrm{mg} \mathrm{kg}^{-1}\right) \\
\end{array}$ & 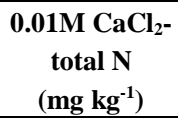 & $\begin{array}{c}\mathrm{O.01M} \mathrm{CaCl} \mathrm{M}^{-} \\
\mathrm{SO}_{4}{ }^{2-} \\
\left(\mathrm{mg} \mathrm{kg}^{-1}\right) \\
\end{array}$ & $\begin{array}{c}1 \mathrm{M} \mathrm{KCl}- \\
\mathrm{SO}_{4}{ }^{2-} \\
\left(\mathrm{mg} \mathrm{kg}^{-1}\right)\end{array}$ & $\begin{array}{c}0.016 \mathrm{M} \mathrm{KH}_{2} \mathrm{PO}_{4^{-}} \\
\mathrm{SO}_{4}{ }^{--} \\
\left(\mathrm{mg} \mathrm{kg}^{-1}\right) \\
\end{array}$ \\
\hline \multirow{3}{*}{ Irrigated } & control & $0.254 \mathrm{a}$ & $1.431 \mathrm{ab}$ & $0.419 a$ & $0.328 \mathrm{a}$ & $6.047 \mathrm{ab}$ \\
\hline & NPK1 & $0.987 \mathrm{a}$ & $2.026 \mathrm{ab}$ & $0.628 \mathrm{a}$ & $0.328 \mathrm{a}$ & $6.124 a b$ \\
\hline & NPK2 & $2.150 \mathrm{~b}$ & $3.550 \mathrm{ab}$ & $1.047 \mathrm{a}$ & $0.421 \mathrm{a}$ & $6.783 \mathrm{~b}$ \\
\hline \multirow{3}{*}{$\begin{array}{c}\text { Non- } \\
\text { irrigated }\end{array}$} & control & $0.433 \mathrm{a}$ & $1.119 \mathrm{a}$ & $0.360 \mathrm{a}$ & $0.421 \mathrm{a}$ & $5.736 \mathrm{ab}$ \\
\hline & NPK1 & $0.762 \mathrm{a}$ & $1.985 \mathrm{ab}$ & $0.293 \mathrm{a}$ & $0.796 \mathrm{a}$ & $5.155 \mathrm{ab}$ \\
\hline & NPK2 & $0.950 \mathrm{a}$ & $4.751 \mathrm{~b}$ & $1.005 \mathrm{a}$ & $1.545 \mathrm{a}$ & $4.535 \mathrm{a}$ \\
\hline
\end{tabular}

Note: Data marked with the same letter is not significantly different at the significant level of $\mathrm{p}<0.05$

The relationship of studied parameters based on the Pearson's correlation

\begin{tabular}{|c|c|c|c|c|c|}
\hline & 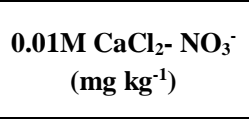 & $\begin{array}{c}0.01 \mathrm{MCaCl}_{2} \text { - total } \\
\mathrm{N} \\
\left(\mathrm{mg} \mathrm{kg}^{-1}\right)\end{array}$ & $\begin{array}{c}\text { 0.01M CaCl} \\
\mathrm{CaCO}_{2} \mathrm{SO}_{4}{ }^{2-} \\
\left(\mathrm{mg} \mathrm{kg}^{-1}\right)\end{array}$ & $\begin{array}{c}1 \mathrm{M} \mathrm{KCl}- \\
\mathrm{SO}_{4}^{2-} \\
\left(\mathrm{mg} \mathrm{kg}^{-1}\right)\end{array}$ & $\begin{array}{c}0.016 \mathrm{M} \mathrm{KH} \mathrm{KOO}_{4}-\mathrm{SO}_{4}{ }^{2-} \\
\left(\mathrm{mg} \mathrm{kg}^{-1}\right)\end{array}$ \\
\hline $\mathrm{N} \%$ & $0.634 * *$ & $0.617 * *$ & - & - & - \\
\hline $\mathrm{S} \%$ & - & - & -0.111 & 0.012 & 0.145 \\
\hline
\end{tabular}

** Correlation is significant at the $\mathrm{p}<0.01$ level

Pearson's correlation was used to determine the relationship between the studied parameters (Table 3). Based on Pearson's correlation analysis positive moderate correlation was detected between the values of $\mathrm{CaCl}_{2} \mathrm{NO}_{3}{ }^{-}, \mathrm{CaCl}_{2}$-total $\mathrm{N}$ and $\mathrm{N}$ content of wheat plant at the stage of $\mathrm{BBCH}$ 30-32. Analysing the correlation between the sulphate content from different soil extractants and the sulphur content of the plant, it can be stated, that weak, almost insignificant relationship was observed, because the $r$ values were always under 0.2. Negative correlation was found between $0.01 \mathrm{M} \mathrm{CaCl}_{2}-\mathrm{SO}_{4}{ }^{2-}$ of soil and sulphur content of the wheat and this value shows inverse relationship between studied values. Kulhanek et al. (2014) calculated the correlation coefficient between bioavailable $S$ contents in soil and percentage $S$ in aboveground biomass and got correlations of about $r=$ 0.30. Obtained results did not correspond with our results.

\section{$\mathrm{N}$-and $\mathrm{S}$ content of plant and soil at the stage of BBCH 61-65 of wheat}

Figure 2 shows the nitrogen-, sulphurconcentration and N/S ratio of winter wheat at the development stage of BBCH 61-65.
The nitrogen content of plant ranged between to 0.87 from $1.87 \%$ in all treatments. Mars (2009) estimated similar values $(0.86-2.22 \%)$ in a long term fertilization experiment. These values are lower, than the nitrogen content of winter wheat at the stage of $\mathrm{BBCH} 30-32$. The effect of increasing fertilizer doses is clearly present in this case too, slightly higher nitrogen content was measured in fertilized plots compared to the control treatment, but this influence was not significant. There was no significant effect of irrigation on plant $\mathrm{N}$ content.

The total sulphur content of winter wheat varied from 0.10 to $0.13 \%$ in all treatments and decreased compared to value of previous development stage. There was no significant effect of irrigation on plant $S$ content. In irrigated areas the NPK fertilization treatments tended to increase the $S$ content of wheat compared to the control treatment. In the case of sulphur content in the non-irrigated area there is no difference between the studied treatments.

The N/S ratios of plant at this development stage were lower compared to the N/S ratio at the stage of stem elongation and this values changed from 8.61 to 14.07 in all treatments. The increasing fertilizer doses enhanced the N/S ratio in this development stage also. 
Figure 2: Changes of N-, S- content and N/S ratio of winter wheat at the stage of BBCH $61-65$

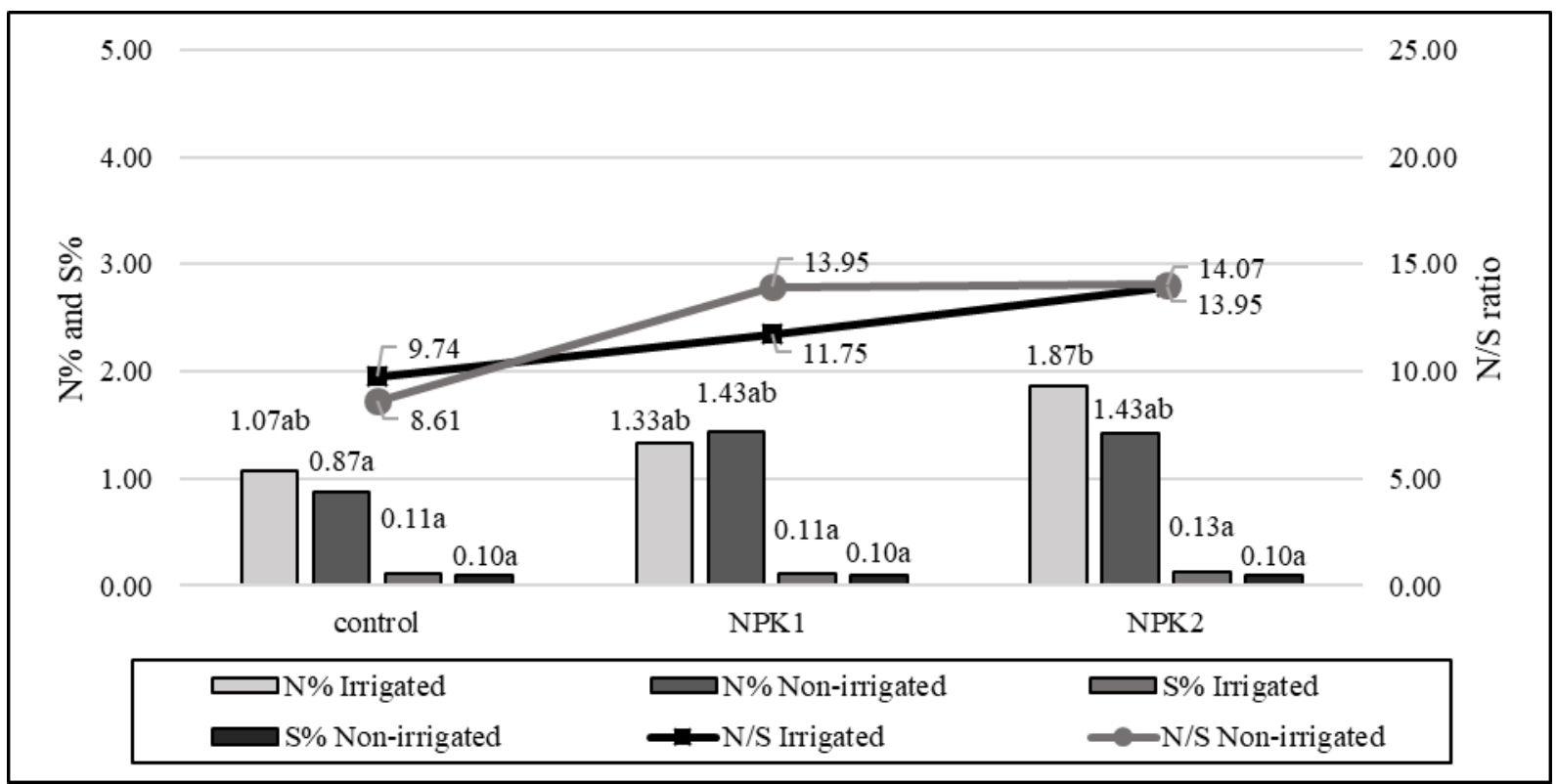

Note: Data marked with the same letter is not significantly different at the significant level of $\mathrm{p}<0.05$

Table 4 illustrated the different forms of sulphur and nitrogen of soil measured in different extractant at the development stage of flowering of winter wheat.

The $\mathrm{CaCl}_{2}$ soluble nitrate- $\mathrm{N}$ content ranged from 0.654 to $3.160 \mathrm{mg} \mathrm{kg}^{-1}$ in all treatments. A slightly increment in nitrate content of soil was observed compared to the stage of $\mathrm{BBCH} 30-32$. It can be probably caused due to the optimal condition for mineralization of the organic nitrogen sources. Regarding the NPK fertilizer treatments it can be stated that this treatment increased the $\mathrm{NO}_{3}{ }^{-} \mathrm{N}$ pool of the soil compared to the control, but this increment was not statistically justified. Higher nitrate content was found in non-irrigated area in all treatment. That can be explained by the fact, that the irrigated treatments probably resulted higher biomass and this caused higher nitrate uptake by the plant and lower nitrate content of the soil compared to the non-irrigated ones. The $\mathrm{CaCl}_{2}$-total $\mathrm{N}$ content varied from 1.946 to 4.367 $\mathrm{mg} \mathrm{kg}^{-1}$ and this value showed same tendencies as the nitrate- $\mathrm{N}$ content.
The $\mathrm{CaCl}_{2}$ soluble sulphate content ranged between 0.837-1.896 mg kg-1. In this case higher sulphate content was measured in non-irrigated plot and the increasing doses of fertilizer resulted higher sulphate content compared to the control treatment.

The $\mathrm{KCl}$ soluble sulphate content at the stage of $\mathrm{BBCH}$ 30-32 was also higher compared to the previous development stage. Except control treatment higher sulphate content was measured in the non-irrigated plots and the higher NPK fertilizer doses resulted higher sulphate content compared to the control treatment and in the non-irrigated plots this effect was statistically proven.

The $\mathrm{KH}_{2} \mathrm{PO}_{4}$ soluble $\mathrm{SO}_{4}{ }^{2-}$ was the highest in this development stage also. The sulphate content in the non-irrigated plots was higher in this case too than the irrigated variant and fertilized treatments tended to increase the sulphate-values, but there is almost no difference between the control and NPK1 treatment both in irrigated and non-irrigated plots.

$\mathrm{NO}_{3}{ }^{-}$, Total $\mathrm{N}$ and $\mathrm{SO}_{4}{ }^{2-}$ - content of soil at the stage of $\mathrm{BBCH} 61-65$ of winter wheat

\begin{tabular}{|c|c|c|c|c|c|c|}
\hline \multicolumn{2}{|c|}{ Treatments } & 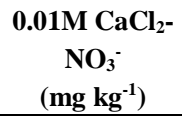 & $\begin{array}{c}0.01 \mathrm{MCaCl}_{2}- \\
\text { total N } \\
\left(\mathrm{mg} \mathrm{kg}^{-1}\right) \\
\end{array}$ & 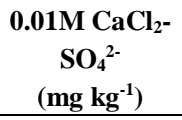 & $\begin{array}{c}1 \mathrm{M} \mathrm{KCl}- \\
\mathrm{SO}_{4}{ }^{2-} \\
\left(\mathrm{mg} \mathrm{kg}^{-1}\right) \\
\end{array}$ & $\begin{array}{c}0.016 \mathrm{M} \mathrm{KH}_{2} \mathrm{PO}_{4-}^{-} \\
\mathrm{SO}_{4}{ }^{2-} \\
\left(\mathrm{mg} \mathrm{kg}^{-1}\right)\end{array}$ \\
\hline \multirow{3}{*}{ Irrigated } & control & $0.654 a$ & $1.946 \mathrm{a}$ & $0.837 \mathrm{a}$ & $1.053 \mathrm{ab}$ & $6.550 \mathrm{a}$ \\
\hline & NPK1 & $1.062 \mathrm{a}$ & $2.278 \mathrm{a}$ & $0.970 \mathrm{a}$ & $1.557 \mathrm{bc}$ & $6.783 a$ \\
\hline & NPK2 & $2.128 \mathrm{a}$ & $3.349 \mathrm{a}$ & $1.058 \mathrm{a}$ & $1.740 \mathrm{bc}$ & $8.566 \mathrm{a}$ \\
\hline \multirow{3}{*}{ Non-irrigated } & control & $0.751 \mathrm{a}$ & $2.015 \mathrm{a}$ & $1.367 \mathrm{a}$ & $0.504 \mathrm{a}$ & $7.597 \mathrm{a}$ \\
\hline & NPK1 & $2.986 a$ & $4.393 \mathrm{a}$ & $1.896 \mathrm{a}$ & $1.786 b c$ & 7.713a \\
\hline & NPK2 & $3.160 \mathrm{a}$ & $4.367 \mathrm{a}$ & $1.852 \mathrm{a}$ & $2.152 \mathrm{c}$ & $8.101 \mathrm{a}$ \\
\hline
\end{tabular}

Note: Data marked with the same letter is not significantly different at the significant level of $\mathrm{p}<0.05$ 
Studying the correlation between the values of $\mathrm{CaCl}_{2}$ soluble $\mathrm{NO}_{3}{ }^{-}$, total $\mathrm{N}$ of soil and $\mathrm{N}$ content of wheat plant at the stage of BBCH 60-65 (Table 5), it can be stated, that this values did not change compared to the previous period, so positive moderate correlation was determined in this case too. The $r$ value between the plant sulphur content and the $\mathrm{CaCl}_{2}$ soluble sulphate increased compared to the previous period and this value refers to a weak, negative connection. With analysing the correlation between the plant S- and soil $\mathrm{S}$ content it can be stated, that weak correlation could also be found. The plant $\mathrm{S}$ and $\mathrm{KCl}-\mathrm{SO}_{4}{ }^{2-}$ showed the strongest correlation, but also weak relationship with $2=0.284$. This correlation value increased compared to the stage of $\mathrm{BBCH} 30-32$.

The relationship of studied parameters based on the Pearson's correlation

\begin{tabular}{|c|c|c|c|c|c|}
\hline & $\begin{array}{c}\mathbf{0 . 0 1 M \mathrm { CaCl } _ { 2 } - \mathrm { NO } _ { 3 } ^ { - }} \\
\left(\mathrm{mg} \mathrm{kg}^{-1}\right)\end{array}$ & $\begin{array}{c}0.01 \mathrm{MCaCl}_{2-}^{-} \\
\text {total N } \\
\left(\mathrm{mg} \mathrm{kg}^{-1}\right)\end{array}$ & 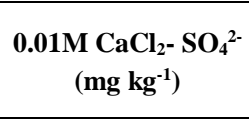 & $\begin{array}{c}1 \mathrm{M} \mathrm{KCl}- \\
\mathrm{SO}_{4}^{2-} \\
\left(\mathrm{mg} \mathrm{kg}^{-1}\right)\end{array}$ & $\begin{array}{c}\mathbf{0 . 0 1 6 \mathrm { M } \mathrm { KH } _ { 2 } \mathrm { PO } _ { 4 } - \mathrm { SO } _ { 4 } { } ^ { 2 }} \\
\left(\mathrm{mg} \mathrm{kg}^{-1}\right)\end{array}$ \\
\hline N\% & $0.632 * *$ & 0.617 *** & - & - & - \\
\hline $\mathrm{S} \%$ & - & - & -0.319 & 0.284 & -0.096 \\
\hline
\end{tabular}

** Correlation is significant at the $\mathrm{p}<0.01$ level

\section{$\mathrm{N}$-and $\mathrm{S}$ content of plant and soil at the stage of BBCH 89 of wheat}

The Figure 3 shows the N-, S content and N/S ratio of winter wheat grain (BBCH 89). The effect of fertilization is clearly prevailed in this case too, but significant higher nitrogen content was measured only in NPK2 treatment both in irrigated and non-irrigated area. There was no significant effect of irrigation on plant $\mathrm{N}$ content. Neither irrigation nor fertilization had effect on the sulphur content of the wheat grain.

Besides $\mathrm{N}$ and $\mathrm{S}$ content of wheat grain, the N/S ratio is a very important factor affecting the bread making quality (Järvan et al., 2008). The smallest N/S ratio was found in the control treatment. The NPK fertilization enhanced this ratio, so the $\mathrm{N}$ content of the grain increased at greater extent than the sulphur content. The highest N/S ratio was found in the wheat grain. Lásztity (1991) came to similar conclusion he investigated the effect of NPK fertilization in a long term experiment on changes of $\mathrm{N} / \mathrm{S}$ ratio of winter wheat during the growing season and the highest N/S ratio was found at the stage of ripening. Györi (1998) estimated the N/S ratio in winter wheat grain in average 15. According to Naeem and Macritchie (2003) the N/S ratio of 17:1 appear to be critical for optimum quality. Randall et al. (1981) came to similar conclusion, he concluded that grain is deficient in $\mathrm{S}$ for both yield and quality if the $\mathrm{N} / \mathrm{S}$ ratio is above 17:1. Although according to Reussi et al. (2012) the use of total sulphur (TS) and N/S ratio in grain as a satisfactory indicators or tools of S supply for wheat based on the thresholds, $0.12 \%$ (TS) and 17:1 (N/S ratios). Comparing the literature data with our results about the critical total sulphur content and the N/S ratio of the wheat grain, sulphur deficiency in the produced winter wheat grain can be assumed.

Figure 3: Changes of N-, S- content and N/S ratio of winter wheat grain at the stage of BBCH 89

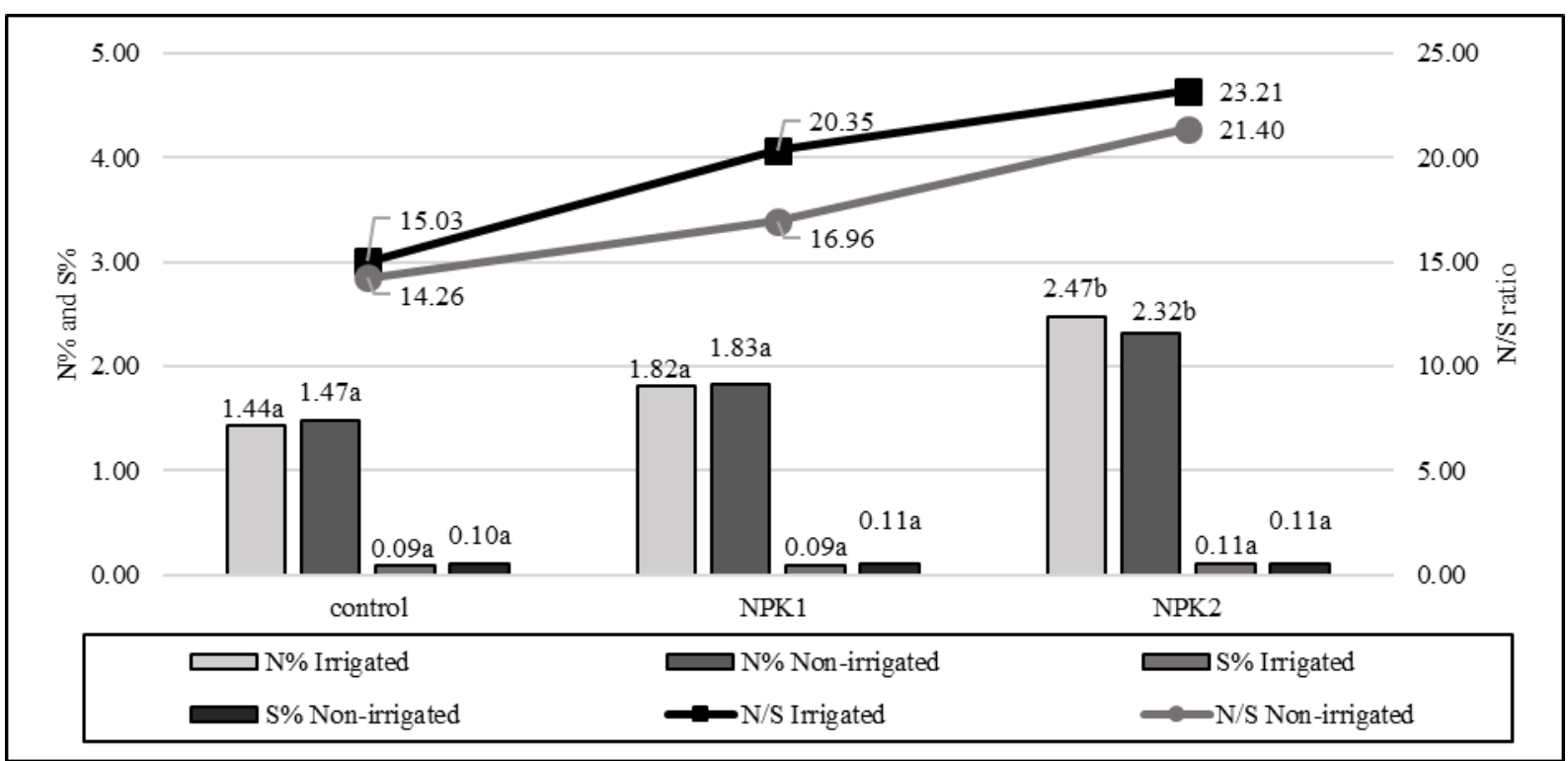

Note: Data marked with the same letter is not significantly different at the significant level of $\mathrm{p}<0.05$ 
The $\mathrm{CaCl}_{2}-\mathrm{NO}_{3}{ }^{-}$content of soil measured at this development stage did not change significantly, but was a little bit lower than the previous period (Table 6). There are no significant differences between the control and NPK1 treatment, only the NPK2 treatment resulted significant increment in nitrate-N content. Analysing the $\mathrm{CaCl}_{2}$ soluble sulphate, it can be stated, that the sulphate content tended to decrease in soil compared to the previous period, might be because of intensive nutrient uptake of plant. At the stage of ripening, the sulphate content in fertilized plots was mostly lower in the irrigated area that can be explained by the fact, that higher yield probably resulted in higher sulphur uptake and lower sulphate content of soil compared to the control. This tendency can be observed in the case of $\mathrm{KCl}$ soluble sulphate content. The $\mathrm{KH}_{2} \mathrm{PO}_{4}$ soluble $\mathrm{SO}_{4}{ }^{2-}$ of soil measured at the ripening stage of wheat ranged between $8.240-10.261 \mathrm{mg} \mathrm{kg}^{-1}$. The lowest sulphate content was measured in control treatments. The effect of increasing fertilizer doses clearly prevailed compared to the control treatment, because these treatments resulted in higher sulphate content both in irrigated and non-irrigated area.

$\mathrm{NO}_{3}{ }^{-}$, Total $\mathrm{N}$ and $\mathrm{SO}_{4}{ }^{2-}$ - content of soil at the stage of $\mathrm{BBCH} 89$ of winter wheat

\begin{tabular}{|c|c|c|c|c|c|c|}
\hline \multicolumn{2}{|c|}{ Treatments } & $\begin{array}{c}0.01 \mathrm{M} \mathrm{CaCl}_{2}- \\
\mathrm{NO}_{3}^{-} \\
\left(\mathrm{mg} \mathrm{kg}^{-1}\right) \\
\end{array}$ & $\begin{array}{c}0.01 \mathrm{MCaCl}_{2^{-}} \\
\text {total N } \\
\left(\mathrm{mg} \mathrm{kg}^{-1}\right) \\
\end{array}$ & $\begin{array}{c}\mathrm{0.01M} \mathrm{CaCl} \mathrm{C}^{-} \\
\mathrm{SO}_{4}{ }^{2-} \\
\left(\mathrm{mg} \mathrm{kg}^{-1}\right) \\
\end{array}$ & $\begin{array}{c}1 \mathrm{M} \mathrm{KCl}- \\
\mathrm{SO}_{4}{ }^{2-} \\
\left(\mathrm{mg} \mathrm{kg}^{-1}\right)\end{array}$ & $\begin{array}{c}0.016 \mathrm{M} \mathrm{KH}_{2} \mathrm{PO}_{4^{-}} \\
\mathrm{SO}_{4}{ }^{2-} \\
\left(\mathrm{mg} \mathrm{kg}^{-1}\right) \\
\end{array}$ \\
\hline \multirow{3}{*}{ Irrigated } & control & $0.777 \mathrm{a}$ & $1.901 \mathrm{a}$ & $1.142 \mathrm{a}$ & $1.847 \mathrm{a}$ & $7.753 \mathrm{a}$ \\
\hline & NPK1 & $0.607 \mathrm{a}$ & $1.718 \mathrm{a}$ & $0.573 \mathrm{a}$ & $1.634 \mathrm{a}$ & $8.706 \mathrm{a}$ \\
\hline & NPK2 & $2.433 \mathrm{~b}$ & $3.963 b$ & $0.397 \mathrm{a}$ & $1.610 \mathrm{a}$ & $9.909 \mathrm{a}$ \\
\hline \multirow{3}{*}{ Non-irrigated } & control & $0.692 \mathrm{a}$ & $1.543 \mathrm{a}$ & $0.461 \mathrm{a}$ & $0.710 \mathrm{a}$ & $8.126 \mathrm{a}$ \\
\hline & NPK1 & $0.755 \mathrm{a}$ & $1.934 \mathrm{a}$ & $0.335 \mathrm{a}$ & $0.568 \mathrm{a}$ & $10.655 \mathrm{a}$ \\
\hline & NPK2 & $1.251 \mathrm{ab}$ & $2.796 \mathrm{ab}$ & $0.544 \mathrm{a}$ & $1.989 \mathrm{a}$ & $10.531 \mathrm{a}$ \\
\hline
\end{tabular}

Note: Data marked with the same letter is not significantly different at the significant level of $\mathrm{p}<0.05$

Based on Pearson's correlation (Table 7) positive moderate correlation was detected between the values of $\mathrm{CaCl}_{2} \mathrm{NO}_{3}{ }^{-}$and $\mathrm{N}$ content of grain. The $\mathrm{r}$ value of grain $\mathrm{N}$ and $\mathrm{CaCl}_{2}$-total $\mathrm{N}$ of the soil showed a positive high correlation. The correlation between the $\mathrm{CaCl}_{2}$ -
$\mathrm{SO}_{4}$ and grain $\mathrm{S}$ content showed negative and moderate relationship. The $\mathrm{r}$ value between the plant $\mathrm{S}$ and $\mathrm{KCl}-$ $\mathrm{SO}_{4}$ didn't show correlation. The $\mathrm{r}$ value between the grain $\mathrm{S}$ and the $\mathrm{KH}_{2} \mathrm{PO}_{4}-\mathrm{SO} 4$ showed a moderate and positive correlation.

The relationship of studied parameters based on the Pearson's correlation

\begin{tabular}{|c|c|c|c|c|c|}
\hline & 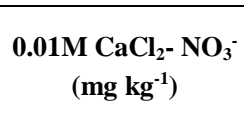 & $\begin{array}{c}\mathbf{0 . 0 1 \mathrm { MCaCl } _ { 2 } \text { - total } \mathrm { N }} \\
\left(\mathrm{mg} \mathrm{kg}^{-1}\right)\end{array}$ & $\begin{array}{c}\text { 0.01M } \mathrm{CaCl}_{2}-\mathrm{SO}_{4}{ }^{2-} \\
\left(\mathrm{mg} \mathrm{kg}^{-1}\right)\end{array}$ & $\begin{array}{c}1 \mathrm{M} \mathrm{KCl}- \\
\mathrm{SO}_{4}^{2-} \\
\left(\mathrm{mg} \mathrm{kg}^{-1}\right)\end{array}$ & 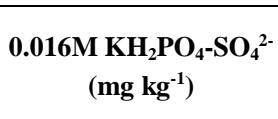 \\
\hline N\% & $0.663^{* *}$ & $0.740 * *$ & - & - & - \\
\hline S\% & - & - & -0.437 & -0.078 & 0.423 \\
\hline
\end{tabular}

** Correlation is significant at the $\mathrm{p}<0.01$ level

\section{CONCLUSIONS}

Based on our results, it can be stated, that the sulphur containing superphosphate supplied in the period of 1984-2010 has no longer significant effect on total sulphur content of plant in 2018. The NPK fertilization treatments had positive effect on total nitrogen content of winter wheat. In general, with increasing NPK doses significant higher nitrogen was measured. However, this can also have a negative impact, because continuous application of $\mathrm{N}$ fertilizer without supplemental sulphur will reduce the bread making quality. The effect of irrigation applied in previous years has no statistically significant effect on sulphur- and nitrogen content of wheat.

Comparing the literature data about critical values of wheat grain (S content: $0.12 \%$; N/S: 17:1) with our measured data (S content: $0.089-0.108 \%$; N/S: 14.26
23.21) it can be said that wheat grain produced in our experiment, especially in fertilized treatments showed $\mathrm{S}$ deficiency. The higher nitrogen supply would also require a better sulphur supply. The increasing $S$ deficiency in plant can have damaging effect, for example reduce the utilization and absorption of other nutrient, especially $\mathrm{N}$.

Analysing the changes of $\mathrm{CaCl}_{2}$ soluble nitrate-N and total $\mathrm{N}$ of the soil, it can be stated, that the effect of increasing fertilizer doses clearly appears in these parameters, because the treatment with increasing fertilizer doses resulted higher $\mathrm{CaCl}_{2}$ soluble $\mathrm{N}$ forms compared to the control treatment in soil. These values increased until flowering stage of wheat and after that a slightly decrease was observed as a result of higher $\mathrm{N}$ uptake of plant.

In overall, it can be stated, that the effect of superphosphate on measured sulphur fraction is 
prevailed. With increasing fertilizer doses higher sulphate content was detected in soil. However, according to many authors (Jaggi et al., 1999; Tandon, 1991), the soil $\mathrm{SO}_{4}{ }^{-2}-\mathrm{S}$ as a critical limit of S deficiency for most crop species (e.g., in wheat) is $10-13 \mathrm{mg} \mathrm{kg}^{-1}$. Based on this value it can be concluded, that the sulphate content measured in different soil extractant is not enough for the wheat in this experiment area.

Studying the correlation between the measured parameters of plant and soil, it can be concluded, that the relationships between nitrogen in the plant and in the soil is stable, and did not change during the growing season. The correlation between plant $S$ and soil $S$ varied in the measured periods and the $r$ value was low in most cases. At the stage of flowering the highest $r$ value was found between $\mathrm{KCl}-\mathrm{SO}_{4}$ and plant $\mathrm{S}$. In the stage of ripening the strongest correlation was detected between $\mathrm{KH}_{2} \mathrm{PO}_{4}-\mathrm{SO}_{4}$ and grain $\mathrm{S}$ content.

\section{ACKNOWLEDGMENT}

The publication was supported by the EFOP-3.6.3VEKOP-16- 2017-00008 project. The project is cofinanced by the European Union and the European Social Fund. The research was financed by the Higher Education Institutional Excellence Programme (204283/2018/FEKUTSTRAT) of the Ministry of Human Capacities in Hungary, within the framework of the 4. thematic programme of the University of Debrecen.

\section{REFERENCES}

Ahmad, A.-Abraham, G.-Gandotra, N.-Abrol, Y.P.-Abdin, M.Z. (1998): Interactive effect of nitrogen and sulphur on growth and yield of rapeseed-mustard (Brassica juncea [L.] Czern 527 and Coss. and Brassica campestris L.). J Agron Crop Sci 181: 193 199. DOI: 10.1111/j.1439-037X.1998.tb00417.x

Barney, P.E. Jr.-Bush, L.P. (1985): Interaction of nitrate and sulfate reduction in tobacco-Influence of availability of nitrate and sulfate, Journal of Plant Nutrition, Volume 8, Issue 6: 505-515. https://doi.org/10.1080/01904168509363363

Cram, W.J. (1990): Uptake and transport of sulphate. In Rennenberg $\mathrm{H}$ (ed.) Sulphur Nutrition and Assimilation in Higher Plants. SPB Academic Publishing, The Hague, The Netherlands, 3-11.

Flaete, N.E.S.-Hollung, K.-Ruud, L.-Sogn, T.-Faergestad, E.M.Skarpeid, H.J.-Magnus, E.M.-Uhlen, A.K. (2005): Combined nitrogen and sulphur fertilisation and its effect on wheat quality and protein composition measured by SE-FPLC and proteomics. Journal of Cereal Science 41: 357-369. https://doi.org/10.1016/j.jcs.2005.01.003

Hesse, H.-Nikiforova, V.-Gakière, B.-Hoefgen, R. (2004): Molecular analysis and control of cysteine biosynthesis: integration of nitrogen and sulphur metabolism, J. Exp.Bot. 55: 1283-1292. https://doi.org/10.1093/jxb/erh136

Houba, V.J.G.-Jászberényi, I.-Loch, J., (1991): Application of $0,01 \mathrm{M} \mathrm{CaCl} 2$ as a single extraction solution for evaluation of the nutritional status of Hungarian soils. Debreceni Agrártudományi Egyetem Tudományos Közleményei. 30: 85-89.

Hu, Z.Y.-Zhao, F.F.-McGrath, S.P. (2005): Sulphur fractionation in calcareous soils and bioavailability to plants, Plant and Soil, 268: 103-109. https://doi.org/10.1007/s11104-004-0229-0

Jaggi, R.C.-Aulakh, M.S.-Sharma, R. (1999): Temperature effects on soil organic sulphur mineralization and elemental sulphur oxidation in subtropical soils of varying $\mathrm{pH}$. Nutrient Cycling in Agroecosystems 54: 175-182. https://doi.org/10.1023/A:1009770919296

Jamal, A.-Fazli, I.S.-Ahmad, S.-Abdin, M.Z.-Yun, S.J. (2005): Effect of sulphur and nitrogen application on growth characteristics, seed and oil yield of soybean cultivars. Korean J Crop Sci 50(5): 340-345.

Jamal, A.-Fazli, I.S.-Ahmad, S.-Abdin, M.Z. (2006) Interactive effect of nitrogen and sulphur on yield and quality of groundnut (Arachis hypogea L.). Korean J Crop Sci 51(6): 519-522.
Jamal, A.-Moon, Y.S.-Abdin, M.Z. (2010): Enzyme activity assessment of peanut (Arachis hypogea) under slow-release sulphur fertilization. Aust J Crop Sci 4(3):169-174.

Järvan, M.-Edesi, L.-Adamson, A.-Lukme, L.-Akk, A. (2008): The effect of sulphur fertilization on yield, quality of protein and baking properties of winter wheat, Agronomy Research 6(2): 459-469.

Kalocsai, R.-Schmidt, R.-Földes, T.-Szakál, P. (2003): A műtrágyázás és elemi kén adagolás hatása a talaj kémhatására és felvehető $\mathrm{SO}_{4}{ }^{2-}$-tartalmára, Agrokémia és Talajtan, 52: 2003 12. https://doi.org/10.1556/Agrokem.52.2003.1-2.10

Kulhánek, M.-Balík, J.-Černy, J.-Sedlár, L.P.O. (2014): Winter wheat fertilizing using nitrogen-sulphur fertilizer, Archives of Agronomy and Soil Science, 2014 Vol. 60, No. 1: 67-74. https://doi.org/10.1080/03650340.2013.771260

Lásztity, B. (1991): Az NPK-tápanyagellátás hatása az őszi búza kéntartalmának és felhalmozásának dinamikájára. Agrokémia és Talajtan 40 (1-2) 131-139.

Mars, É (2009): A kéntrágyázás hatása az őszi búza minőségi és mennyiségi paramétereinek alakulására, $\mathrm{PhD}$ értekezés, Debreceni Egyetem

McGrath, S.P.-Zhao, F.J. (1996): Sulphur uptake, yield response and the interactions between $\mathrm{N}$ and $\mathrm{S}$ in winter oilseed rape (Brassica napus L.) J Agric Sci 126: 53-62. https://doi.org/10.1017/S0021859600088808

Naeem, H.A.-Macritchie, F. (2003): Effect of Sulphur Nutrition on Agronomic and Quality Attributes of Wheat, Sulphur in Plants; 305-322. https://doi.org/10.1007/978-94-017-0289-8_17

Parsons, J.W.-Tinsley, J. (1975): Nitrogenous substances. In Soil Components Vol. I (Ed.: Gieseking, J.E.), Springer-Verlag, Berlin and New York.263-304. DOI: 10.1007/978-3-642-659157_3

Pepó, P. (2015): Use of long-term experiments to determine the impact of agro technical practices in wheat (Triticum aestivum L.) and maize (Zea mays L.) production. Aspects of Applied Biology. 128: 231-237.

Randall, P.J.-Spencer, K.-Freney, J.R. (1981): Sulphur and nitrogen fertilizer effects on wheat. I Concentrations of sulphur and nitrogen and the nitrogen to sulphur ratio in grain in relation to the yield response. Aust. J. Agric. Res. 32:203-212. https://doi.org/10.1071/AR9810203

Reussi, N.-Echeverria, H.E.-Rozas, H.S. (2012): Stability of foliar $\mathrm{N} / \mathrm{S}$ ratio in spring red wheat and sulphur dilution curve. 
J Plant Nutrition. 2012; 35(7): 990-1003. https://doi.org/10.1080/01904167.2012.671403

Ruiter, J.M.-Martin, R.J. (2001): Management of nitrogen and sulphur fertilizer for improvement bread wheat (Triticum aestivum) quality. New Zealand Journal of Crop and Horticultural Science 29: 287-299. https://doi.org/10.1080/01140671.2001.9514190

Sahota, T.S. (2006): Importance of Sulphur in Crop Production. Northwest Link, September, 10-12.
Tandon, H.L.S. (1991): Sulphur Research and Agricultural Production in India. ( ${ }^{\text {rd }}$ Edition) The Sulphur Institute, Washington DC, USA. 200.

Zhao, F.-McGrath S.P. (1994): Extractable sulphate and organic sulphur in soils and their availability to plants. Plant Soil 164: 243-250. https://doi.org/10.1007/BF00010076

Zhao, F.J.-Hawkesford, M.J.-McGrath, S.P. (1999): Sulphur assimilation and effects on yield and quality of wheat. J Cereal Sci. 30:1-17. https://doi.org/10.1006/jcrs.1998.0241 
